Reddy, S.M. \& Occhipinti, S. 2004. High-strain zone deformation in the southern Capricorn Orogen, Western Australia: Kinematics and age constraints. Precambrian Research, 128, 295314.

\title{
High-strain zone deformation in the southern Capricorn Orogen, Western Australia: Kinematics and age constraints
}

\author{
Steven M. Reddy \& Sandra A. Occhipinti \\ ${ }^{1}$ Tectonics Special Research Centre, School of Applied Geology, Curtin University of Technology, PO Box \\ U1987, Perth, WA 6845, Australia.
}

Key Words: shear zone, structure, deformation, tectonics, Palaeoproterozoic, Yilgarn

Correspondence to Steve Reddy (e-mail: S.Reddy@.curtin.edu.au) 


\begin{abstract}
Detailed structural mapping of a the Kerba Fault, a high-strain zone along the contact between the Archaean to Palaeoproterozoic Yarlarweelor Gneiss Complex (partly derived from the Yilgarn Craton) and the Palaeoproterozoic volcano-sedimentary rocks of the Bryah Group, indicate a temporal progression from foliation development to folding and finally brittle deformation. Structural data from the penetrative $S_{1}$ foliation indicate a superficially simple geometry and kinematic history with a single, pervasive, greenschist facies foliation forming during dextral strike slip shearing. However, systematic spatial variations in the magnitude and orientations of mineral elongation lineations indicate a more complex deformation history involving a combination of general transpressive dextral shear and subsequent reactivation. This deformation has previously been considered to develop between 1830-1780 Ma ago during the Capricorn Orogeny. Relative age relationships around the Kerba Fault indicate that the high strain deformation postdates the intrusion of the Kerba Granite at $1808 \pm 6 \mathrm{Ma}$. Analysis of available age data indicates that the minimum age of deformation is poorly constrained. However, evidence from regionally similar structures and geochronological data indicate that deformation associated with high-strain zones in the southern Capricorn Orogen may be Mesoproterozoic in age — significantly younger than the Capricorn Orogeny.
\end{abstract}




\section{Introduction}

The Capricorn Orogen of Western Australia lies between the Yilgarn and Pilbara cratons (Fig.1) and is thought to have developed during the amalgamation of the two cratons during the Palaeoproterozoic (Tyler and Thorne, 1990). The orogen records a complex Proterozoic tectonic history involving multiple phases of deformation, metamorphism and granite formation. However, one of the most significant structural features is the presence of numerous regional-scale high-strain zones that delimit the different tectonic units in the region. These high-strain zones have been recognised for some time (Condon, 1962; Williams et al., 1983) but they have only previously been mapped at a regional scale. Although previous mapping has recognised significant structural complexity within the shear zones, with the orientations of mineral lineations and shear directions being variable (Sheppard and Occhipinti, 2000), detailed studies on the structural and kinematic evolution of the high-strain zones have not been published.

A study of Capricorn high-strain zones is essential in establishing the kinematics and timing of Yilgarn - Pilbara collision and the tectonic amalgamation of the West Australian Craton during the Palaeoproterozoic. In this study, we consider the structural evolution and kinematic history of deformation at the southern margin of the Capricorn Orogen. We document geometric and kinematic structural data and present a detailed analysis of constraints on the timing of high-strain zone formation. We concentrate on the Kerba Fault, a greenschist facies structure that juxtaposes the Archaean-Palaeoproterozoic Yarlarweelor Gneiss Complex with metamorphic rocks of the Palaeoproterozoic volcano-sedimentary rocks of the Bryah Group (Fig. 1) and is thought to have developed during the Capricorn Orogen at $1800 \mathrm{Ma}$ (Occhipinti and Myers, 1999).

\section{Geological Background}

The southern Capricorn Orogen is characterised by several regional lithotectonic units that have complex igneous, deformation and metamorphic histories. The Yarlarweelor Gneiss Complex represents Archaean granitic gneiss of the Narryer Terrane that was deformed, metamorphosed and intruded by voluminous granite in the Palaeoproterozoic (Occhipinti and Myers, 1999; Sheppard and Swager, 1999). Granitic gneiss of the Narryer Terrane, was heterogeneously deformed and metamorphosed during at least three late Archaean orogenic events (Williams and Myers, 1987; Occhipinti and Myers, 1999). To the south and east, the 
Yarlarweelor Gneiss Complex is in tectonic contact with volcano-sedimentary units of the Bryah and Padbury Groups. These groups have been recently described in some detail (Hynes and Gee, 1986; Occhipinti et al., 1996; Pirajno and Occhipinti, 1998; Pirajno et al., 1998; Martin, 1999; Occhipinti and Myers, 1999; Pirajno and Occhipinti, 2000). Four formations have been identified in the Bryah Group but only one of these, the Narracoota Formation, is recognised in the study area (Occhipinti and Myers, 1999). This formation is characterised by metamorphosed mafic and ultramafic schists, basalt and gabbros and has been interpreted as an Archaean greenstone belt (Elias and Williams, 1980), an allochthonous ophiolite complex (Myers, 1999) and more recently as developing within a rift basin (Hynes and Gee, 1986; Pirajno and Occhipinti, 1998). A maximum age for the Bryah Group of $2014 \pm 22$ Ma has been obtained by SHRIMP U-Pb dating of detrital zircons (Nelson, 1996). The Padbury Group stratigraphically overlies the Bryah Group and comprises siliciclastic, carbonate and chemical sedimentary rocks with a maximum depositional age of $1996 \pm 35$ Ma (Nelson, 1997).

Previous workers have subdivided the Palaeoproterozoic tectonic history of the southern Capricorn Orogen into several regional deformation and metamorphic events (Table 1). Originally these were all attributed to deformation during the Capricorn Orogeny (Occhipinti et al., 1998; Occhipinti and Myers, 1999; Sheppard and Swager, 1999). However, more recent studies integrating U-Pb SHRIMP zircon data have been able to discriminate between two different orogenic events: the Glenburgh Orogeny and the Capricorn Orogeny (Sheppard and Occhipinti, 2000; Occhipinti and Sheppard, 2001) (Table 1).

The older Glenburgh Orogeny produced extensive granitic magmatism, metamorphism and deformation between 2000 - 1960 Ma (Occhipinti et al., 2003) and reflects the collision and accretion of the Glenburgh Terrane (a late Archaean to Palaeoproterozoic microcontinent of the Gascoyne Complex) onto the northwestern margin of the Yilgarn Craton along the Errabiddy Shear Zone (Occhipinti et al., 2003). On a regional scale, the first Glenburgh deformation event $\left(D_{1 \mathrm{~g}}\right)$ was associated with the formation of foliations and isoclinal folds at granulite to amphibolite conditions between 1990-1975 Ma (Sheppard and Occhipinti, 2000). A second Glenburgh deformation $\left(\mathrm{D}_{2 \mathrm{~g}}\right)$ is associated with foliation, shear zones and fold development at amphibolite facies metamorphic conditions between 1975 - $1960 \mathrm{Ma}$ (Sheppard and Occhipinti, 2000; Occhipinti et al., 2003). 
Most recent interpretations of Capricorn Orogeny deformation have recognised extensive intrusion of granite and two regional deformation events between 1820 - $1780 \mathrm{Ma}$ (Sheppard and Occhipinti, 2000; Occhipinti and Sheppard, 2001). This igneous activity and deformation is commonly associated with either the oblique collision of the Archaean Pilbara and Yilgarn (including the Glenburgh Terrane) cratons (Tyler and Thorne, 1990) or intracratonic orogenesis (Gee, 1979). Granites dated between 1820 and 1780 Ma reportedly record pre-, syn- and post-tectonic relationships with an extensive regional deformation event $\left(D_{1 \mathrm{n}}\right)$ (Sheppard and Occhipinti, 2000; Occhipinti and Sheppard, 2001). This deformation gave rise to meso- to regional- scale upright folds that have variable hinge orientations on a regional scale. $D_{1 \mathrm{n}}$ was also associated with the formation of shear zones with variably oriented mineral elongation lineations (Sheppard and Occhipinti, 2000). Kinematic indicators associated with shear zone mineral lineations show variable senses of shear (Sheppard and Occhipinti, 2000). Metamorphism $\left(\mathrm{M}_{1 \mathrm{n}}\right)$ associated with $\mathrm{D}_{1 \mathrm{n}}$ is generally poorly constrained because the ubiquitous granitic gneisses are poor indicators of metamorphic grade. However, amphibolite or upper amphibolite facies mineral assemblages and textures suggestive of highto medium- metamorphic grades have been reported in the Yarlarweelor Gneiss Complex (Sheppard and Swager, 1999).

The second deformation event $\left(\mathrm{D}_{2 \mathrm{n}}\right)$ associated with the Capricorn Orogeny produced subvertical ductile-brittle shear zones that commonly have dextral offsets (Sheppard and Occhipinti, 2000). These zones of localised deformation contain variably developed foliations, lineations and folds. Lineations within the shear zones are again variably oriented. Mineral assemblages associated with $D_{2 n}$ structures are indicative of greenschist-facies metamorphic conditions (Sheppard and Occhipinti, 2000) and deformation is thought to have taken place around 1800 Ma ago.

In this paper we concentrate on unravelling the complexities of this $\mathrm{D}_{2 n}$ deformation by concentrating on the Kerba Fault a structure previously interpreted to have developed during the Capricorn $\mathrm{D}_{2 \mathrm{n}}$ event (Sheppard and Occhipinti, 2000). We do this by considering two small areas in some detail. These areas have been mapped and a detailed investigation of the relative age relationships between different structures has been undertaken following the technique of (Potts and Reddy, 1999). Here we provide a summary of this data to document the structural evolution of this high-strain zone. 


\section{Structural Geology of the Kerba Fault (Area 1)}

Area 1 is located $8 \mathrm{~km}$ west of Trillbar Homestead at 2532' South and $117^{\circ} 40^{\prime}$ East. In this area, three main units are present: the reworked Archaean granitic rocks of the Yarlarweelor Gneiss Complex, mafic-ultramafic rocks of the Narracoota Formation of the Bryah Group and a complex tectonic contact zone that contains rocks from both units (Fig. 2).

The Yarlarweelor Gneiss Complex in Area 1 mainly consists of foliated and metamorphosed granitic gneiss with minor mafic schists. The granitic gneiss contains several different granitic protoliths that define a well-developed gneissic banding. The granitic rocks comprise quartz, K-feldspar, plagioclase and white mica but are texturally variable. The most common rock type is foliated porphyritic granitic gneiss containing K-feldspar porphyroclasts $(5 \mathrm{~mm}$ diameter), interpreted to have been originally phenocrysts, within a finer ( $<1 \mathrm{~mm}$ diameter) matrix. Coarser and finer equigranular, quartzo-feldspathic layers are also present (Fig. 3a,b) and in low-strain areas these are clearly dykes (Fig. 3c). The banding within the granitic gneiss is parallel to a well-developed planar foliation (Fig. 3a,b). A foliated mafic amphibolite within the main granitic gneiss (Fig. 2) lies parallel to the gneissic banding and foliation.

The Bryah Group in Area 1 comprises mafic rocks that have been extensively deformed and metamorphosed. Two different rock types can be recognised (Fig. 2); a massive dark unit comprised of dark green actinolite and a chlorite-actinolite schist. These are inferred to be derived from pyroxenite and peridotite protoliths respectively (Occhipinti and Myers, 1999). Separating the Yarlarweelor Gneiss Complex and the Bryah Group is a 20-30 m wide contact zone containing two intermixed rock types with affinities to the two adjacent units (Fig. 2). Interbanded chlorite-actinolite schists and quartz-mica rocks are interpreted to represent mafic and felsic igneous protoliths respectively. The southern margin of the contact zone is marked by a 0.3 m wide intensely deformed ultramylonitic quartzite which may represent Bryah Group stratigraphy or a deformed quartz vein. Locally small pods of quartz are present throughout the contact zone. These probably represent reworked quartz veins.

Mineral assemblages throughout Area 1 indicate greenschist facies metamorphic conditions. No evidence for higher grades of metamorphism was observed within the studied area. 


\subsection{Deformation in the Yarlarweelor Gneiss Complex of Area 1}

The Yarlarweelor Gneiss Complex contains a well-developed pervasive foliation $\left(\mathrm{S}_{1}\right)$, which dips steeply to the NNE with a WSW/ESE strike (Fig 4a). $S_{1}$ lies parallel to gneissic banding and is broadly parallel to the regional orientation of the contact (Fig. 2). The $\mathrm{S}_{1}$ foliation becomes more intense towards the contact with the Bryah Group. Quartz and white mica mineral lineations $\left(\mathrm{L}_{1}\right)$, plunging gently to moderately NW (Fig. $4 \mathrm{~b}$ ), are variably developed on the foliation. Mineral lineations are best developed in higher strain rocks towards contact with the Bryah Group (Fig. 2), although, a contact-parallel zone of rocks with mineral lineations is also found in the NE of the mapped area (Fig. 2). Away from these areas, a mineral elongation lineation was not developed within the granitic gneiss.

Well-developed kinematic indicators are seen throughout the granitic gneisses at both outcrop and thin-section scale. These include asymmetric K-feldspar porphyroclasts and extensional crenulation cleavages (shear bands) (Fig. 3a,b). Kinematic indicators show a consistent dextral shear sense, with a minor reverse dip-slip component, independent of whether or not a mineral lineation is developed on the foliation.

In high-strain zones forming by simple shear the width of the zone should remain constant. However several structures indicate that this may not be the case in Area 1. In one location, the pervasive foliation is axial planar to folds that deform a fine-grained granitic dyke (Fig. 3e, 4c). Shortening of the folded layer is c. $40 \%$ perpendicular to the foliation. These folds $\left(F_{1}\right)$ have hinges that lie parallel to the mineral lineation developed in the gneiss and axial surface parallel to $S_{1}$ and are interpreted as developing synchronously with the foliation. In another location, a layer within the granitic gneiss contains layer-oblique shear zones that have sinistral displacements. Flanking folds affecting the $S_{1}$ foliation adjacent to these structures suggest that the shear zones have undergone dextral rotation and that the shear zones accommodate antithetic displacement associated with dextral shear. The geometry of these structures indicates that in the horizontal plane, the gneissic layer underwent layerperpendicular shortening and finite extension along its length, with maximum extension parallel to the mineral lineation on the foliation surface.

A second deformation folds the pervasive $S_{1}$ foliation. These folds $\left(F_{2}\right)$ are generally on the sub-metre scale and are tight to isoclinal (Fig. 3f) and their axial planes lie broadly parallel to the regional $\mathrm{S}_{1}$ foliation (cf. Fig. $4 \mathrm{a} \& \mathrm{c}$ ). Fold hinges have variable orientations and plunge to both NW and SE (Fig. 4d) and most of the fold hinges are orthogonal to the mineral lineation 
(cf. Figs. 4b \&d). However, these folds are only found in close proximity to the contact with the Bryah Group, which has mineral lineations that lie sub-parallel to the fold hinges.

Locally, south-vergent, open chevron $\left(F_{3}\right)$ folds also overprint $S_{1}$. These folds have discrete, steeply dipping, E-W striking axial surfaces (Fig. 4c). $\mathrm{F}_{3}$ fold hinges are moderately east plunging. These folds are small-scale and both mapping and the foliation data (Fig. 4a) indicate no large-scale folds. Relative age relationships of $F_{3}$ and $F_{2}$ folds were not directly observed. However, the different styles of fold deformation are consistent with the chevron folds developing at lower temperatures than the tight-isoclinal ductile $\mathrm{F}_{2}$ structures, suggesting that $\mathrm{F}_{3}$ folds postdate the tight-isoclinal $\left(\mathrm{F}_{2}\right)$ folds.

The $S_{1}$ foliation and $F_{2}$ folds are cut by discrete, foliation-parallel brittle faults that have variable slickenlines lineations (Fig. 4e). These faults are best recognised where the faults ramp across the foliation, producing cut-offs (Fig. 2 \& 3d). These structures consistently ramp northwards (Fig. 2) and form complex fault arrays. Folds associated with these faults are common and both antiforms related to ramping and synformal fault bend folds are observed. These folds have axial plane and hinge orientations similar to the $F_{3}$ chevron folds and they may have developed at approximately the same time.

Three sets of well-developed fractures are consistent through the area (Fig. 3g). The three fracture sets have geometries consistent with formation as tensile and conjugate shear fractures (Fig. 4f), possibly indicating shallow N-S oriented $\sigma_{1}$, sub-vertical $\sigma_{2}$ and E-W oriented $\sigma_{3}$ stresses during fracture formation. Several generations of quartz veins and a single foliation-oblique fault are also present in the area.

\subsection{Deformation in the Bryah Group in Area 1}

The structure of the Bryah Group appears much simpler than that of the adjacent gneiss. The main structural feature is a pervasive foliation that is parallel to the nearby gneissic foliation and contact of the two units (Fig. 4a). Mineral lineations lying on the foliation are rarely developed but one actinolite lineation plunges moderately to the east (Fig. 4b). No folds were observed in the Bryah Group, although the contact of the Bryah Group and the contact zone (see section 3.3) is folded (Fig. 2). A single fault trending NE-SW is inferred from the offset of compositional layering within the Bryah Group (Fig. 2). There is no evidence of foliationparallel brittle faults similar to those seen in the gneiss. 


\subsection{Deformation in the contact zone of Area 1}

The rock types preserved in the contact zone are similar to those seen in the adjacent granitic gneiss and mafic schist. However, in rocks of granitic origin feldspars are commonly altered to sericite and mafic rocks are more chlorite rich than in the adjacent units. All rock types in the contact zone are strongly foliated and foliations have locally well-developed mineral lineations. The orientation of the foliation is steeply dipping and ESE-WNW striking and is geometrically similar to that seen in the adjacent rocks (Fig. 4a). However, the orientation of mineral lineations is distinctly different from that seen in the gneiss complex and they plunge moderately to the SE, similar to the single lineation seen in the Bryah Group (Fig. 4b). Kinematic indicators within the contact zone are difficult to see in hand specimen. However, in thin section they indicate a dextral shear sense.

Folds within the contact zone are rare. However, the ultramylonite that is taken as the southern margin of the contact zone with the Bryah Group is locally tightly folded at the submetre scale (Fig. 2). These folds have steep axial surfaces that are broadly parallel to the regional foliation orientation (Fig. 4c), and SE plunging hinges (Fig. 4d), which have similar orientations to mineral lineations within the contact zone (Fig. 4d). The folds are asymmetric and are consistently northward verging (Fig. 2).

Post-dating all other structures in the contact zone are three sets of fractures that have similar orientations to those seen in the gneiss.

\section{Structural Geology of the Kerba Granite \& the Bryah Group Contact (Area 2)}

Area 2 is located approximately $10 \mathrm{~km} \mathrm{SE} \mathrm{of} \mathrm{Area} \mathrm{1,} \mathrm{along} \mathrm{the} \mathrm{contact} \mathrm{of} \mathrm{the} \mathrm{Kerba} \mathrm{Granite}$ and the Bryah Group (Fig. 1). Three main units can be distinguished; granitic gneiss of the Kerba Granite, schists of the Bryah Group and a contact zone separating these units (Fig. 5).

The Kerba Granite is a biotite monzogranite intruded into gneisses of the Yarlarweelor Gneiss Complex at $1808 \pm 6 \mathrm{Ma}$ (Nelson, 1998). It is a medium- to coarse- grained granite containing quartz, feldspar and white mica (Fig. 6a,b). Fine-grained leucocratic dykes intrude the granite and towards the contact with the Bryah Group their number increases. Where strongly deformed, the leucocratic dykes become very platy (Fig. 6c) and are mapped as fine-grained gneiss (Fig. 6). Amphibolite seen in the lower strain parts of the Kerba Granite (Fig. 5) is foliated and has a greenschist facies mineralogy. The amphibolite may be derived from mafic 
dykes that intruded the Kerba Granite or may be xenoliths of mafic material within the granite.

The Bryah Group in Area 2 is dominated by mica schists with minor quartz mylonites and metabasic rock types. These are strongly deformed by a strong and pervasive foliation. The contact zone is a generally poorly exposed c. $25 \mathrm{~m}$ wide zone that has characteristics of both adjacent units. The contact zone is strongly banded and intensely foliated.

\subsection{Deformation in the Kerba Granite of Area 2}

The Kerba Granite becomes progressively more foliated towards the contact with the Bryah Group. The zone of high strain is at least $300 \mathrm{~m}$ wide. The foliation in the Kerba Granite (including the leucocratic and mafic dykes) dips steeply to the north (Fig. 7a) and locally contains a quartz and white mica elongation lineation. These lineations have a variable orientations (Fig. 7b) with ESE-plunging lineations changing to WNW-plunging towards the contact. Kinematic indicators, including shear bands, asymmetric porphyroclasts and mica fish, indicate a consistent dextral sense of shear (Figs 6a,b).

The $S_{1}$ foliation within the Kerba Granite and associated leucocratic dykes is locally overprinted by a series of tight to isoclinal folds (Fig. 6c), interpreted to be associated with a second deformation $\mathrm{D}_{2}$, and referred to as $\mathrm{F}_{2} . \mathrm{F}_{2}$ folds are generally small (with amplitudes < $50 \mathrm{~cm}$ ) and asymmetric. Folds closer to the contact indicate vergence to the north while the few folds seen distal to the contact are south verging. No larger scale fold structure was seen between the two opposing vergence directions and the change in vergence may reflect younger faulting separating different limbs of a larger fold structure. The folds have axial planar orientations broadly parallel to the regional orientation of the foliation in the contact zone (Fig. 7a,c). Hinges associated with these axial surfaces are variable and show a similar distribution to mineral lineations (Fig. 7b,d).

Locally metre-scale chevron folds (Fig. 6d) with SE-NW striking, steeply dipping axial surfaces and steeply plunging hinges are present (Fig. 7c, d). These folds are asymmetric and SW verging. Their relationship to $F_{2}$ folds and foliation-parallel faults is unclear as no relative age relationships were observed. However, the more open, angular nature of the folds, the obliquity to the main foliation and the development of discrete axial surfaces suggests lower grade conditions than $\mathrm{F}_{2}$. 
There are several generations of faults present within Area 2. A number of steeply dipping, discrete faults lie broadly parallel to lithological banding and the main foliation. These are poorly exposed but are recognised because they locally step across and cut either lithological boundaries between the Kerba Granite and fine-grained gneiss or the foliation. These faults are commonly $1 \mathrm{~cm}$ wide and appear to be brittle deformation features. The faults cut through both $\mathrm{F}_{2}$ and $\mathrm{F}_{3}$ folds. In two locations foliation-parallel quartz veins associated with these faults have slickenlines that indicate dip-slip displacements on the fault surfaces (Fig. 7e). Other faults are also present in the area. These are poorly exposed but form topographic features across which displacements of lithological layers occur. Faults have three general orientations: NE-SW striking, NW-SE striking and E-W striking (Fig. 5). The NW striking faults are parallel to a well-developed fracture set present throughout Area 2 (Fig. 7f).

\subsection{Deformation of the Bryah Group in Area 2}

The dominant structure is a pervasive, steeply dipping, E-W striking foliation defined by closely spaced mica and quartz domains (Fig. 7a), which lie parallel to the contact (Fig. 5). The $S_{1}$ foliation lies axial planar to folds defined by bedding $\left(F_{1}\right)$ that have moderately SE plunging fold hinges (Fig. 7d). The $S_{1}$ foliation is also deformed by tight, upright folds $\left(F_{2}\right)$ and these folds have an associated axial planar foliation $\left(F_{2}\right)$. The orientation of $F_{2}$ and $F_{1}$ are similar, and in areas where fold closures are not present, discrimination of $S_{1}$ and $S_{2}$ is difficult. Composite $S_{1} / S_{2}$ and $F_{1} / F_{2}$ orientations are shown in the stereonets (Fig. 7c,d). $F_{1}$ and $F_{2}$ axial planes and fold hinges within the Bryah Group are parallel to those recorded in the Kerba Granite (Fig. 7c,d). A quartz and mica mineral lineation that also plunges to the ESE is locally present on the composite $\mathrm{S}_{1} / \mathrm{S}_{2}$ foliation. This orientation is the same as that in the Kerba Granite away from the contact (Fig. 7b). Mineral lineations and fold hinge orientations in the Bryah Group are subparallel (Fig 7b,d).

A leucocratic granitic dyke intruded into the Bryah Group is folded by $F_{2}$ and also by a younger phase of open folding $\left(F_{3}\right)$ that has a similar orientation to $F_{3}$ seen in the deformed Kerba Granite. This folded dyke is cut by a NW-striking fault (Fig. 5).

\subsection{Deformation in the contact zone of Area 2}

The contact zone between the Kerba Granite and the Bryah Group is structurally complex. All rocks in the contact zone contain a strong, pervasive foliation that parallels the $S_{1}$ foliation seen in the surrounding Kerba Granite and Bryah Group (Fig. 7a). This foliation $\left(\mathrm{S}_{1}\right)$ is 
parallel to lithological layering in the contact zone. In quartz-rich rocks the foliation is mylonitic. Mineral lineations associated with the foliation are distinctly different from that in the Bryah Group and plunge moderately to the NW, parallel to lineations in the Kerba Granite that lie proximal to the contact zone (Fig. 7b). However, unlike the Kerba Granite, no kinematic indicators were observed within the contact zone.

In mylonitic quartz-rich rocks, the $S_{1}$ foliation is folded to produce a series of tight to isoclinal folds $\left(\mathrm{F}_{1}\right)$ that do not have a good axial planar fabric associated with them. Individual fold hinges are often strongly curvilinear and some have sheath type geometries. Type 3 fold interference patterns are locally present indicating a second folding event $\left(F_{2}\right)$ deformed the quartz mylonites within the contact zone. The $\mathrm{F}_{2}$ folds are tight to isoclinal and have axial plane and hinge orientations similar to the $\mathrm{F}_{1}$ folds. They also have a weakly developed axial planar foliation $\left(\mathrm{S}_{2}\right)$. The variable nature of contact zone axial planes and hinges (Fig. 7c,d) reflect both the non-cylindricity of folding and the superposition of two folding episodes.

A series of fractures and faults affect rocks in the contact zone. The orientations of these structures are similar to those described in the Kerba Granite and Bryah Group.

\section{Discussion}

\subsection{Structural History of the Kerba Fault}

The geometries and relative age relationships of structures in Areas $1 \& 2$ have been summarised in two schematic block diagrams (Fig. 8). Generally the two areas show very similar structural histories progressing from foliation development to folding and finally faulting. Each unit in each area is characterised by the early development of pervasive greenschist facies foliations that appear to represent the first deformation phase. The orientation of these foliations is similar in all units in both areas and is broadly parallel to the orientation of the local contact between the Yarlarweelor Gneiss Complex and Bryah Group.

Foliation development within Areas 1 and 2 is heterogeneous and deformation increases markedly towards the contact. This indicates that pervasive deformation in Areas $1 \& 2$ is related to contact strain. However, relative age relationships between the ' $S_{1}$ ' foliations in the contact zone and the surrounding units do not exist so we cannot assume that the foliation in the contact zone developed at the same time as the foliation in the surrounding rocks. In the Yarlarweelor Gneiss Complex and the Kerba Granite, mineral lineations associated with the 
$\mathrm{S}_{1}$ foliation are also heterogeneously developed. However, there is no systematic spatial relationship between lineation development and the contact (Figs. 2 \& 5).

The distribution of strain that can be inferred from the orientation of $S_{1}$ foliations and associated mineral lineations $\left(\mathrm{L}_{1}\right)$ is complex. The orientation of foliation planes in deformed rocks is commonly interpreted as the XY plane of the finite strain ellipse, with mineral elongation lineations indicating the direction of maximum stretch $(\mathrm{X})$ in that plane. Mineral elongation lineations associated with the consistently oriented $S_{1}$ foliations are heterogeneously developed suggesting variations in the shape of the finite strain ellipse throughout the mapped areas. Mineral elongation lineations also have variable orientations, suggesting a difference in the orientation of principal stretches associated with finite strain. Within Area 1, the NW plunging X-direction in the gneiss differs significantly from the SE plunging mineral lineation that developed in the contact zone and Bryah Group (Fig 4b, 8a). In Area 2, the contact zone and immediately adjacent Kerba Granite have a NW-plunging Xdirection, while the Bryah Group and contact-distal Kerba Granite have SE-plunging Xdirections (Fig. 7b, 8b). These features indicate different strain histories between the contact zone and surrounding rocks. In addition the contact zone granitic rocks differ from adjacent gneiss in that feldspars are intensely altered to sericite. This indicates a greater degree of retrograde reaction and suggests increased fluid flow in the contact zone. Localised fluid flow in the contact zone at the same time as deformation in the surrounding rocks or may indicate a younger, localised deformation affected the contact zone rocks.

Despite, the variations in the orientation of the maximum finite stretches, kinematic indicators are pervasively developed within the gneiss and contact zone of Area 1 and the Kerba Granite in Area 2, independent of whether a mineral elongation lineation is developed within the rock. These indicate a consistent dextral wrench component associated with foliation development and suggests that dextral shear was associated with juxtaposition of the Yarlarweelor Gneiss Complex with the Bryah Group. Previous work around the Kerba Fault has recorded mylonite development associated with dextral shearing but the contact of the Yarlarweelor Gneiss Complex and the Bryah Group has been interpreted as a south-directed thrust (Occhipinti and Myers, 1999). Despite detailed observations at the contact, we have found no evidence to support this. 
Granitic rocks in both areas have small-scale, tight to isoclinal folds $\left(F_{2}\right)$ that deform the $S_{1}$ fabric. These folds have similarly oriented axial planes that are broadly parallel to the regional orientation of the $S_{1}$ foliation. The orientation of $F_{2}$ fold hinges is variable. However in most cases, the orientations of the $\mathrm{F}_{2}$ hinges are parallel to the orientation of the mineral lineation $\left(\mathrm{L}_{1}\right)$ on the deformed $\mathrm{S}_{1}$ foliation surfaces. A similarity in the orientation of different structures may reflect similar boundary conditions during different deformation events. However, the similarity of local lineation and fold hinge orientations that vary systematically throughout the high-strain zone suggests a link between the formation of $F_{2}$ folds and the orientation of local maximum stretching associated with foliation development. Although relative age relationships indicate that $F_{2}$ post-dates $S_{1}$ formation, a possible explanation for the coincidence of $F_{2}$ hinges and $L_{1}$ directions is that $F_{2}$ folds developed during the later stages of the deformation that produced $S_{1}$. In the absence of absolute age data, we interpret $\mathrm{D}_{1}$ and $\mathrm{D}_{2}$ to be two stages of a single progressive deformation.

$\mathrm{F}_{2}$ folds in both Areas $1 \& 2$ are truncated, and therefore post-dated, by a series of dominantly foliation-parallel detachments that give rise to foliation cut-offs and, in Area 1, ramp antiforms and fault-bend folds $\left(\mathrm{F}_{3}\right)$. The style of deformation associated with these detachments and the $\mathrm{F}_{3}$ folds suggest lower grade deformation than that associated with the formation of $S_{1}$ and $F_{2}$. The two dimensional nature of the outcrop and the absence of kinematic information that can be directly linked to movement on these detachments means that the direction and magnitude of displacement of the detachments cannot be constrained. However, the similarity in deformation intensity and rock types across these structures suggests that they accommodate only small amounts of deformation. Importantly, these features indicate reactivation of the $S_{1}$ foliation at a later stage in the deformation history

Brittle deformation in both areas $1 \& 2$ is evident in well-developed fracture sets and faults that transect the areas. The geometry of the three sets of fractures are consistent with tensile and conjugate shear fractures that indicate a maximum principal stress $\left(\sigma_{1}\right)$ parallel to the minimum finite stretch of the strain ellipse associated with foliation $\left(\mathrm{S}_{1}\right)$ development. This may indicate a period of continued compression perpendicular to the foliation during the latter stages of the deformation history of this region. The kinematics associated with faulting could not be constrained because none of the mapped fault zones were exposed and piercing points across faults could not be constructed. 


\subsection{Tectonic Models for Deformation}

The variations in S-L fabric intensity and the different orientations of mineral lineations indicate heterogeneous strain magnitude and geometry during high-strain zone development. These features are not consistent with a model of localisation of simple shear deformation at the contact of the granitic rocks and the Bryah Group (Fig. 9a) and a more complex model is required.

The geometries of foliations, lineations and kinematic indicators within high-strain zones are often used to establish the kinematic history of rock deformation. Such information has been used to establish the relative displacements of different parts of the crust and thereby construct tectonic histories (Goodge et al., 1993; Wheeler and Butler, 1993; Passchier, 1994). The basis for this approach has often been the assumption that high-strain zones deform by simple shear: a situation that allows lineations formed on C-surfaces to be related to transport directions, with the sense of shear being inferred from the geometry of structures that are asymmetric across the plane of the foliation (Ramsay, 1980; Hanmer and Passchier, 1991). However, during natural deformation the operation of only simple shear deformation is unlikely and the deformation may involve combined pure and simple shear components, referred to as 'general shear' or 'transpression' if the pure shear component is compressional (Harland, 1971).

Recent theoretical modelling of transpression has considered the geometry and magnitude of both finite and incremental strain in systems involving different magnitudes and orientations of pure and simple shear components. These models predict patterns of deformation that are far more complex than those produced by simple shear alone (Sanderson and Marchini, 1984; Fossen and Tikoff, 1993; Robin and Cruden, 1994; Tikoff, 1994; Jones et al., 1997; Fossen and Tikoff, 1998; Jiang and Williams, 1998; Lin et al., 1998; Passchier, 1998). An important conclusion of these models is that the orientation of finite strain axes associated with transpression may change as deformation progresses. This will affect foliation and lineation orientations and, as a result, mineral stretching lineations in transpressional high-strain zones need not correspond to tectonic transport directions (see above references).

In this study, kinematic indicators record consistent dextral kinematics and this is independent of lineation intensity and orientation. We conclude that the juxtaposition of the Yarlarweelor Gneiss Complex and Bryah Group took place during deformation that had significant 
component of dextral strike-slip shear. However, the varying orientation of $\mathrm{L}_{1}$ may reflect variations in the localisation of pure shear across the contact during deformation. Several features suggest that there may have been a component of foliation-orthogonal shortening associated with foliation development. The rare $\mathrm{F}_{1}$ folds present in the gneissic rocks developed synchronously with $S_{1}$, have fold hinges parallel to the maximum principal stretch and indicate at least $40 \%$ shortening of layers orthogonal to the foliation. Discrete zones within the gneiss complex, which have antithetic shears that are more closely spaced than the width of the zone, indicate foliation-orthogonal shortening and lengthening parallel to $L$ at the same time as dextral shearing. Compression orthogonal to the $S_{1}$ foliation appears to have continued in the later stages of the deformation history as illustrated by the widespread development of tensile and conjugate fractures. These observations, linked with the heterogeneous development of mineral lineations and the variable orientation of $\mathrm{X}$ on consistently oriented $S_{1}$ foliations are consistent with a model of general shear involving simultaneous component of both pure and simple shear (e.g. Fig 9b) and we conclude that the formation of the high-strain zone was probably associated with transpressional flow.

High-strain zones are recognised as rheologically weak zones that may undergo reactivation during subsequent deformation (Butler et al., 1997). Geometric reactivation, in which subsequent phases of deformation have different displacement direction, may be recognised by systematic variations in kinematics within a high-strain zone. Kinematic reactivation, where the structure is reactivated by deformation with the same shear sense is more difficult to recognise. However, variations in metamorphic grade between different deformation events can be used to infer a time difference between deformation phases. Similarly, variations in the distribution and nature of deformation products in shear zones may be used to infer reactivation (Holdsworth et al., 1997). However, the spatial and temporal migration of strain, and associated variations in strain rate, may yield complex overprinting relationships during a single progressive deformation event. As a result, structural criteria for documenting reactivation in high-strain zones may be equivocal.

Geochronological criteria can be used to demonstrate reactivation if the timing of different high strain fabrics can be constrained. The absolute timing of deformation can be obtained by dating minerals that crystallised during the deformation but this requires knowledge of isotopic closure temperature, the deformation temperature and the nature of deformation of the mineral being dated (Reddy and Potts, 1999). However, data from a high-strain zone in the Italian Alps indicates that greenschist facies deformation took place over $\sim 9$ Ma (Reddy et 
al., 1999). This deformation fits the definition of reactivation (Holdsworth et al., 1997) but appears to represent a single, progressive deformation in which strain migrates spatially and temporally (Reddy et al., 1999).

In Areas $1 \& 2$, the variation in $\mathrm{L}_{1}$ orientation may reflect the overprinting or reactivation of early-developed foliations by subsequent deformation (Fig. 9c). All foliations developed at greenschist facies conditions and record dextral strike-slip kinematics with only a minor dipslip component. However, we cannot rule out reactivation of early $S_{1}$ foliations by a deformation at a similar metamorphic grade with a similar kinematic framework in the contact zone. Since relative age relationships can not be used to demonstrate the synchronicity of foliation development across the areas, the possibility of reactivation of structures developed during an earlier part of the deformation history cannot be discounted. The presence of tightly refolded isoclinal folds and enhanced retrograde overprinting in the contact zone that are absent from the adjacent deformed parts of the shear zone may be further evidence of later, localised deformation and associated alteration. We suggest that the contact zone is probably a zone of reactivation of currently unknown age.

\subsection{The Absolute Timing of Deformation in the Southern Capricorn Orogen}

Deformation in the southern Capricorn Orogen has previously been subdivided into three events (Table 1) (Occhipinti and Myers, 1999). The first event, their $\mathrm{D}_{1 \mathrm{n}}$, produced a pervasive foliation and may have been responsible for the tectonic interleaving of the Bryah Group with the Yarlarweelor Gneiss Complex. This episode of deformation has been subsequently related to Glenburgh deformation (Sheppard and Occhipinti, 2000; Occhipinti and Sheppard, 2001; Occhipinti et al., 2003) (refer to Table 1). Although evidence for the Glenburgh Orogeny is pervasive in the western part of the Capricorn Orogen, there is little evidence for Glenburgh deformation in the east. Our data indicate that the juxtaposition of the Yarlarweelor Gneiss Complex with the Bryah Group along the Kerba Fault took place after intrusion of the Kerba Granite at c.1808 Ma, and we have found no evidence to support earlier tectonic interleaving of these units.

We have shown that the strain associated with the pervasive $S_{1}$ foliation in both the Yarlarweelor Gneiss Complex (Area 1) and Kerba Granite (Area 2) is complex. However, since all deformation seen in this contact region post dates the intrusion of the Kerba Granite, then all of the deformation described in this paper corresponds to the $\mathrm{D}_{2 \mathrm{n}}$ deformation event 
of Sheppard and Occhipinti (2000), Occhipinti and Sheppard (2001) and Occhipinti et al (2003) (refer to Table 1). The minimum age for southern Capricorn Orogen $D_{2 n}$ deformation has been constrained as $1797 \pm 4$ Ma (Nelson, 1998; Occhipinti et al., 1998); the age of a weakly sigmoidal, $140-170^{\circ}$ striking granite dyke inferred to have intruded during the late stages of $\mathrm{D}_{2 \mathrm{n}}$ deformation (Occhipinti et al., 1998; Sheppard and Swager, 1999; Sheppard et al., 2002). However, there are several reasons why this the age of $D_{2 n}$ deformation may be younger than $1797 \pm 4$ Ma.

The dyke that yielded the $c .1797$ Ma age is one of a suite of biotite granites that forms a pluton and numerous dykes around the Morris Fault, a splay off the Errabiddy Shear Zone (Occhipinti et al., 1998) (Fig. 1). Two of these biotite granites have been dated and both ages are in agreement of an intrusion age at c.1797 Ma (Occhipinti et al., 1998), possibly suggesting that the suite is temporally restricted. Reported field relationships (Occhipinti et al., 1998) Sheppard, 1999 \#6182] indicate that the analysed granitic dyke post-dates a ductile deformation and high-grade metamorphism, although it is not clear whether this deformation represents earlier Glenburgh $\left(\mathrm{D}_{1 \mathrm{~g}}\right)$ or Capricorn $\left(\mathrm{D}_{1 \mathrm{n}}\right)$ deformation. However, the granite dykes have been metamorphosed at greenschist facies conditions (Occhipinti et al., 1998).

The weakly sigmoidal shape of some of the biotite granites has been used to argue that they were intruded syn-tectonically into the Morris Fault (Occhipinti et al., 1998). The sigmoidal geometry may indicate that the dyke margins were folded by an external deformation and that the absence of internal tectonic fabrics may suggest that this deformation took place before the granite crystallised. However, microstructural observations (Nelson, 1998) indicates that the dyke has undergone minor deformation, while biotite granites belonging to the same igneous suite are strongly foliated (Sheppard and Swager, 1999). The fact that some of the biotite granites are strongly deformed indicates that some of the $\mathrm{D}_{2 n}$ deformation post-dates dyke intrusion and that the suite of biotite granites record heterogeneous $\mathrm{D}_{2 n}$ deformation. The absence of internal strain in the 1797 Ma dyke cannot therefore be used to argue that the dyke formed after or during the later stages of $\mathrm{D}_{2 \mathrm{n}}$, because the dyke may lie within a domain of low $\mathrm{D}_{2 \mathrm{n}}$ strain.

A further complexity in assessing the minimum age of $\mathrm{D}_{2 n}$ deformation comes from the analysis of published maps of the area from which the minimum age of $\mathrm{D}_{2 \mathrm{n}}$ was constrained 
(Sheppard and Swager, 1999). These show a series of granitic rocks (Discretion Granite) dated at $1619 \pm 15$ Ma that are cut by structures that have a similar orientation to the Kerba Fault studied here. The available temporal evidence therefore suggests that at least some of these regional scale structures formed or were reactivated since c. $1600 \mathrm{Ma}$. Observations from other areas support the assertion that some of the deformation within the Capricorn Orogen is younger than $1800 \mathrm{Ma}$. For example, shear zones in the Gascoyne basement to the north of the mapped area can be traced into folds in the overlying Bangemall Supergroup. Since the maximum age of Bangemall Supergroup sedimentation is c. $1638 \pm 14$ Ma (Nelson, 1995; Martin and Thorne, 2001), the reactivation of basement shear zones must have occurred since then.

We conclude that the age of $1797 \pm 4$ Ma cannot be used to constrain the minimum age of $D_{2 n}$ deformation in the area studied in detail in this paper. The only absolute age constraints that can be placed on the deformation history presented here is that the pervasive deformation associated with foliation development (local $S_{1}$ ) is younger than the intrusion of the Kerba Granite at $1808 \pm 6 \mathrm{Ma}$. The only other geochronological data available to constrain the deformation is Rb-Sr biotite data that show a significant difference in closure ages from $c$. $800 \mathrm{Ma}$ in the Yarlarweelor Gneiss Complex to c. 1545 Ma in the Narryer Terrane (Libby et al., 1999). Although this difference could be explained by differential erosion, it may also support tectonic activity between the two units during the period 1600-800 Ma.

\section{Conclusions}

The structural evolution of a regional-scale, high-strain zone at the southern margin of the Yarlarweelor Gneiss Complex is characterised by a heterogeneous deformation history. However, all valid deformation histories indicate a temporal sequence of foliation development, folding and faulting. Superficially the deformation at the southern margin of the Yarlarweelor Gneiss Complex seems relatively simple with a pervasive greenschist facies foliation with well-preserved dextral strike-slip kinematic indicators. However, although foliation orientations across the high-strain zone are similar along the length of the contact, variations in the intensity and orientation of mineral elongation lineations indicate variations in the magnitude and orientation of finite strain within the high-strain zone. These variations in strain may reflect heterogeneously distributed pure and simple shear during transpressional 
flow. However, data also indicate the likely reactivation of the high-strain zone at greenschist facies conditions.

Kinematic indicators suggest juxtaposition of the Yarlarweelor Gneiss Complex and the Bryah Group took place by dextral strike-slip shear with only a minor dip-slip component. No evidence was found for thrusting along the margin of the YGC and the Bryah Group. Available geochronological information indicate that the complex deformation history highlighted in this study post-dates the intrusion of the Kerba Granite at c.1808 Ma and corresponds to the second phase of Capricorn deformation at a regional scale $\left(\mathrm{D}_{2 \mathrm{n}}\right)$. There are no available age constraints on the minimum age of this deformation or the age of subsequent reactivation. After careful analysis of relative age relationships in the southern Capricorn Orogen, we conclude that the regionally recognised $\mathrm{D}_{2 \mathrm{n}}$ Capricorn deformation (senso Occhipinti \& Sheppard 2001) is likely to be spatially and temporally far more complex than previously recognized.

\section{Acknowledgements}

This work was funded by the Australian Research Council. Dave Gray and an anonymous reviewer are thanked for detailed reviews of the manuscript. Logistical support from the Geological Survey of Western Australia is gratefully acknowledged. The paper is Tectonics Special Research Centre Publication No. 203.

\section{References}

Butler, R.H.W., Holdsworth, R.E. and Lloyd, G.E., 1997. The role of basement reactivation in continental deformation. Journal of the Geological Society, London, 154: 69-71.

Condon, M.A., 1962. Glenburgh, Western Australia:, Australian Bureau of Mineral Resources.

Elias, M. and Williams, S.J., 1980. Robinson Range, Western Australia, Western Australia Geological Survey, Perth, WA.

Fossen, H. and Tikoff, B., 1993. The deformation matrix for simultaneous simple shearing, pure shearing and volume change, and its application to transpression - transtension tectonics. Journal of Structural Geology, 15: 413-422.

Fossen, H. and Tikoff, B., 1998. Extended models of transpresson and transtension, and application to tectonic settings. In: R.E. Holdsworth, R.A. Strachan and J.F. Dewey (Editors), Continental Transpressional and Transtensional Tectonics. Geological Society Special Publication, pp. 15-33.

Gee, R.D., 1979. Structure and tectonic style of the Western Australian shield. Tectonophysics, 58: 327-369.

Goodge, J.W., Hansen, V.L., Peacock, S.M., Smith, B.K. and Walker, N.W., 1993. Kinematic evolution of the Miller Range Shear Zone, Central Transantarctic Mountains, Antarctica, and implications for Neoproterozoic to Early Paleozoic tectonics of the East Antarctic margin of Gondwana. Tectonics, 12(6): 1460-1478.

Hanmer, S. and Passchier, C.W., 1991. Shear-sense indicators: a review. Geological Survey of Canada, Paper 90-17, 72 pp.

Harland, W.B., 1971. Tectonic transpression in Caledonian Spitzbergen. Geological Magazine, 108: 27-42.

Holdsworth, R.E., Bultler, C.A. and Roberts, A.M., 1997. The recognition of reactivation during continental deformation. Journal of the Geological Society, London, 154: 73-78. 
Hynes, A. and Gee, R.D., 1986. Geological setting and petrochemistry of the Narracoota Volcanics, Capricorn Orogen, Western Australia. Precambrian Research, 31(2): 107-132.

Jiang, D. and Williams, P.F., 1998. High-strain zones: a unified model. Journal of Structural Geology, 20(8): 1105-1120.

Jones, R.R., Holdsworth, R.E. and Bailey, W., 1997. Lateral extrusion in transpression zones: the importance of boundary conditions. Journal of Structural Geology, 19: 1201-1217.

Libby, W.G., deLaeter, J.R. and Armstrong, R.A., 1999. Proterozoic biotite Rb-Sr dates in the northwestern part of the Yilgarn craton, Western Australia. Australian Journal Of Earth Sciences, 46: 851-860.

Lin, S., Jiang, D. and Williams, P.F., 1998. Transpression (or transtension) zones of triclinic symmetry: natural example and theoretical modelling. In: H. R.E., R.A. Strachan and J.F. Dewey (Editors), Continental Transpressional and Transtensional Tectonics. Geological Society, London, Special Publication, pp. 41-57.

Martin, D.M., 1999. Lithostratigraphy and structure of the Palaeoproterozoic Padbury Group, Milgun 1:100 000 sheet, Western Australia. 62, Western Australia Geological Survey, Perth, WA.

Martin, D.M. and Thorne, A.M., 2001. New Insights into the Bangemall Supergroup. Record 2001/5, Geological Survey of Western Australia, Perth.

Myers, J.S., 1999. Thrust sheets on the southern foreland of the Capricorn Orogen, Robinson Range, Western Australia. 62, Western Australia Geological Survey Professional Papers, Perth, WA.

Nelson, D.R., 1995. Compilation of SHRIMP U-Pb zircon geochronology data, 1994. West Australian Geological Survey, Record 1995/3: 244.

Nelson, D.R., 1996. Compilation of SHRIMP U-Pb zircon geochronology data, 1995, Record 1996/5. West Australian Geological Survey, Perth, 168 pp.

Nelson, D.R., 1997. Compilation of SHRIMP U-Pb zircon geochronology data, 1996. 1997/2, Geological Survey of Western Australia, Perth, Australia.

Nelson, D.R., 1998. Compilation of SHRIMP U-Pb zircon geochronology data, 1997, Record 1998/2. Geological Survey of Western Australia, Perth, 242 pp.

Occhipinti, S.A. and Myers, J.S., 1999. Geology of the Moorarie 1:100 000 sheet, Western Australia Geological Survey, Perth, WA.

Occhipinti, S.A., Passchier, C., Sheppard, S., Tyler, I.M. and Nelson, D., 2003. Palaeoproterozoic crustal accretion and collision in the southern Capricorn Orogen: The Glenburgh Orogeny. Precambrian Research, this volume.

Occhipinti, S.A. and Sheppard, S., 2001. Geology of the Glenburgh 1:100 000 sheet, Western Australia Geological Survey, Perth, WA.

Occhipinti, S.A., Sheppard, S., Nelson, D.R., Myers, J.S. and Tyler, I.M., 1998. Syntectonic granite in the southern margin of the Palaeoproterozoic Capricorn Orogen, Western Australia. Australian Journal Of Earth Sciences, 45: 509-512.

Occhipinti, S.A., Swager, C.P. and Pirajno, F., 1996. Structural and stratigraphic relations of the Padbury Group, Western Australia - implications for tectonic history. Geological Survey of Western Australia, 19951996 Annual Report: 88-95.

Passchier, C.W., 1994. Structural geology across a proposed Archaean terrane boundary in the eastern Yilgarn craton, Western Australia. Precambrian Research, 68: 43-64.

Passchier, C.W., 1998. Monoclinic model shear zones. Journal of Structural Geology, 20: 1121-1137.

Pirajno, F. and Occhipinti, S.A., 1998. Geology of the Bryah 1:100 000 sheet, Western Australia Geological Survey, Perth, WA.

Pirajno, F. and Occhipinti, S.A., 2000. Three Palaeoproterozoic basins - Yerrida, Bryah and Padbury, Capricorn Orogen, Western Australia. Australian Journal Of Earth Sciences, 47: 675-688.

Pirajno, F., Occhipinti, S.A. and Swager, C.P., 1998. Geology and tectonic evolution of the Palaeoproterozoic Bryah, Padbury and Yerrida Basins (formerly Glengarry Basin), Western Australia: implications for the history of the south-central Capricorn Orogen. Precambrian Research, 90: 119-140.

Potts, G.J. and Reddy, S.M., 1999. Construction and systematic assessment of relative deformation histories. Journal of Structural Geology, 21: 1245-1253.

Ramsay, J.G., 1980. Shear zone geometry: a review. Journal of Structural Geology, 2: 83-99.

Reddy, S.M. and Potts, G.J., 1999. Constraining absolute deformation ages: The relationship between deformation mechanisms and isotope systematics. Journal of Structural Geology, 21: 1255-1265.

Reddy, S.M., Wheeler, J. and Cliff, R.A., 1999. The geometry and timing of orogenic extension: an example from the Western Italian Alps. Journal of Metamorphic Geology, 17: 573-589.

Robin, P.Y.F. and Cruden, A.R., 1994. Strain and vorticity patterns in ideally ductile transpression zones. Journal of Structural Geology, 16(4): 447-466.

Sanderson, D.J. and Marchini, W.R.D., 1984. Transpression. Journal of Structural Geology, 6: 449-458. 
Sheppard, S. and Occhipinti, S.A., 2000. Geology of the Errabiddy and Landor 1:100 000 sheet, Western Australia Geological Survey, Perth, WA.

Sheppard, S., Occhipinti, S.A. and Tyler, I.M., 2002. The relationship between tectonism and composition of granite magmas, Yarlarweelor Gneiss Complex, Western Australia. Lithos, In press.

Sheppard, S. and Swager, C.P., 1999. Geology of the Marquis 1:100 000 sheet, Western Australia Geological Survey, Perth, WA.

Tikoff, B.a.T., C., 1994. Strain modeling of displacement-field partitioning in transpressional orogens. Journal of Structural Geology, 16: 1575-1588.

Tyler, I.M. and Thorne, A.M., 1990. The northern margin of the Capricorn Orogen, Western Australia - an example of an Early Proterozoic collision zone. Journal of Structural Geology, 12: 685-701.

Wheeler, J. and Butler, R.H.W., 1993. Evidence for extension in the western Alpine orogen - The contact between the oceanic Piemonte and overlying continental Sesia units. Earth and Planetary Science Letters, 117: 457-474.

Williams, I.R. and Myers, J.S., 1987. Archaean geology of the Mount Narryer region, Western Australia. Report, 22, Western Australia Geological Survey, Perth, WA.

Williams, S.J., Williams, I.R. and Hocking, R.M., 1983. Glenburgh, W. A., Western Australia Geological Survey, Perth, WA. 


\section{Table Caption}

Table 1. Summary of previous structural subdivisions of the southern Capricorn Orogen, Western Australia. Subscripts ‘g' and ‘n’ denote Glenburgh and Capricorn Orogenies respectively.

\section{Figure Captions}

Figure 1. Regional map of the southern Capricorn Orogen after Occhipinti and Myers (1999). The locations of Areas 1 \& 2 mapped in detail in this study (Figs. 2 \& 5) are shown.

Figure 2. Map of the southern margin of the Yarlarweelor Gneiss Complex where it is in contact with deformed and retrogressed mafic units of the Bryah Group (Area 1). X marks field camp at $\mathrm{S} 25^{\circ} 32^{\prime} 13^{\prime \prime} \mathrm{E} 117^{\circ} 40^{\prime} 47^{\prime \prime}$.

Figure 3. Field photographs of structures within Yarlarweelor Gneiss Complex granitic gneiss. a) Lithological banding and well-developed $\mathrm{S}_{1}$ foliation. Shear bands in the coarser granitic layer shows a dextral sense of shear. b) Asymmetric feldspar porphyroclasts indicating a top-to-right sense of shear corresponding to dextral reverse shear sense. c) Pre-S ${ }_{1}$ quartz vein truncated by granitic dyke recording $F_{1}$ fold with axial planar $S_{1}$ foliation developed in the surrounding granitic gneiss. d) $S_{1}$ foliated granitic gneiss cut by post- $S_{1}$ detachment marked by dashed line. Hangingwall foliation is approximately parallel to the detachment while in the footwall the foliation is truncated. e) Granitic dyke showjng $F_{1}$ fold with axial planar $S_{1}$ foliation. f) $F_{2}$, north-verging fold deforming $S_{1}$ foliation. g) Conjugate fractures cutting $S_{1}$ foliation.

Figure 4. Lower hemisphere, equal area stereographic projections of data from Area 1. YGC = Yarlarweelor Gneiss Complex.

Figure 5. Map of the southern margin of the Kerba Granite where it is in contact with deformed micaschists and mafic units of the Bryah Group (Area 2). X marks field camp at S253’07” E11744’42”.

Figure 6. Field photographs of structures within deformed Kerba granite on the southern margin of the Yarlarweelor Gneiss Complex. a) $S_{1}$ Foliation in Kerba. b) Asymmetric feldspar porphyroclasts and shear bands indicating dextral shear. c) $F_{2}$ fold deforming $S_{1}$ foliation in deformed Kerba Granite. d) Platy $S_{1}$ foliation in fine-grained felsic gneiss. 
Protolith of this unit is inferred to be leucogranite dykes that intrude the Kerba Granite. Fold structure is an $\mathrm{F}_{3}$ fold.

Figure 7. Lower hemisphere, equal area stereographic projections of data from Area 2. YGC = Yarlarweelor Gneiss Complex.

Figure 8. Schematic summary of structural features in Areas 1 \& 2. Note the variation of mineral lineation orientations on $\mathrm{S}_{1}$ foliation surfaces indicating variations in the orientation of maximum stretch across the contact zone in both areas.

Figure 9. Schematic end-member models to explain the possible structural development of the Yarlarweelor Gneiss Complex/Kerba Granite and Bryah Group contact. V = vorticity vector. a) Model indicating simple shear at the contact. Pale lines indicate orientation of gouge-type lineations on shear planes. At high strains, rotation of the main foliation (XY) towards parallelism with shear planes will result in mineral lineations (X) lying parallel to shear direction. Kinematics associated with deformation are dextral. Model does not readily account for the observed variation in mineral lineation orientations. b) Transpression model assuming partitioning of pure and/or simple shear components during a single progressive deformation. Such a process can explain variations in $\mathrm{L}_{1}$ (X direction) formed during a single high strain deformation event. c) Model involving polyphase deformations and reactivation of $\mathrm{S}_{1}$ foliation, with $L_{1}$ lineation, by later simple shear sub-parallel to $S_{1}$. Localised high strain reactivation of dextral-shear related $S_{1}$ results in the development of new mineral lineations $\left(L_{2}\right)$. Model assumes variations in vorticity vector orientation $\left(V_{1} \& V_{2}\right)$ that could not be established from field observations. The high-strain zone probably developed by a combination of (b) and (c). 
Table 1:

\begin{tabular}{|c|c|c|}
\hline Occhipinti et al. (1998) & $\begin{array}{l}\text { Occhipinti \& Myers (1999); } \\
\text { Sheppard \& Swager (1999) }\end{array}$ & $\begin{array}{l}\text { Sheppard \& Occhipinti (2000); } \\
\text { Occhipinti \& Sheppard (2001); } \\
\text { Occhipinti et al. (2002). }\end{array}$ \\
\hline \multirow[t]{2}{*}{\begin{tabular}{l}
\multicolumn{1}{c}{ D1 } \\
Sub-horizontal foliations and \\
mylonites; Recumbent folds; \\
Tectonic interleaving between \\
YGC and Bryah-Padbury \\
Groups; N-S compression. \\
Capricorn Orogeny
\end{tabular}} & \begin{tabular}{l}
\multicolumn{1}{c}{$\mathbf{D 1}_{\mathbf{n}}$} \\
Sub-horizontal foliations and \\
tight folding in Bryah- \\
Padbury Groups; Tectonic \\
interleaving between proto- \\
YGC and Bryah-Padbury \\
Groups; N-S compression. \\
Capricorn Orogeny \\
\end{tabular} & $\begin{array}{l}\quad \mathbf{D 1}_{\mathbf{g}} \\
\text { Sub-horizontal gneissic foliations } \\
\text { \& isoclinal folds at granulite and } \\
\text { amphibolite facies } \\
\text { Glenburgh Orogeny }\end{array}$ \\
\hline & & $\begin{array}{l}\quad \mathbf{D} \mathbf{2}_{\mathbf{g}} \\
\text { Foliation development \& } \\
\text { recumbent folds at amphibolite } \\
\text { facies; Tectonic interleaving } \\
\text { between YGC and Bryah- } \\
\text { Padbury Groups; NW or W - SE } \\
\text { or S compression. } \\
\text { Glenburgh Orogeny }\end{array}$ \\
\hline \begin{tabular}{l}
\multicolumn{1}{c}{ D2 } \\
Meso-scale and regional \\
upright folds in Bryah- \\
Padbury Groups and YGC; N- \\
S compression. \\
Capricorn Orogeny
\end{tabular} & $\begin{array}{l}\qquad \mathbf{D 2}_{\mathrm{n}} \\
\text { Meso-scale and regional } \\
\text { upright folds in Bryah- } \\
\text { Padbury Groups and YGC; } \\
\mathrm{N} \text {-S compression. } \\
\text { Capricorn Orogeny }\end{array}$ & $\begin{array}{l}\qquad \mathbf{D 1}_{\mathbf{n}} \\
\text { Meso-scale and regional upright } \\
\text { folds in Bryah-Padbury Groups } \\
\text { and YGC suggesting N-S } \\
\text { compression at amphibolite } \\
\text { facies. Shear zones. Variable } \\
\text { hinge and lineation orientations } \\
\text { Capricorn Orogeny }\end{array}$ \\
\hline \multicolumn{3}{|l|}{\begin{tabular}{l}
\multicolumn{1}{c}{ D3 } \\
E-W compression, upright \\
folds, foliation. \\
Capricorn Orogeny \\
\end{tabular}} \\
\hline \begin{tabular}{l}
\multicolumn{1}{c}{ D4 } \\
Small-scale folds, upright \\
foliation, shear zones and \\
faults; trending E-ESE. \\
Capricorn Orogeny
\end{tabular} & $\begin{array}{l}\qquad \mathbf{D 3}_{\mathbf{n}} \\
\text { Sub-vertical, ESE- trending, } \\
\text { brittle-ductile shear zones. } \\
\text { Conjugate faults; folds; local } \\
\text { mylonites. } \\
\text { Capricorn Orogeny }\end{array}$ & $\begin{array}{l}\qquad \mathbf{D} \mathbf{2}_{\mathbf{n}} \\
\text { Sub-vertical brittle-ductile ESE- } \\
\text { trending shear zones; conjugate } \\
\text { faults; folds and mylonites forming } \\
\text { at greenschist facies conditions. } \\
\text { Variable lineations and hinge } \\
\text { orientations } \\
\text { Capricorn Orogeny }\end{array}$ \\
\hline
\end{tabular}




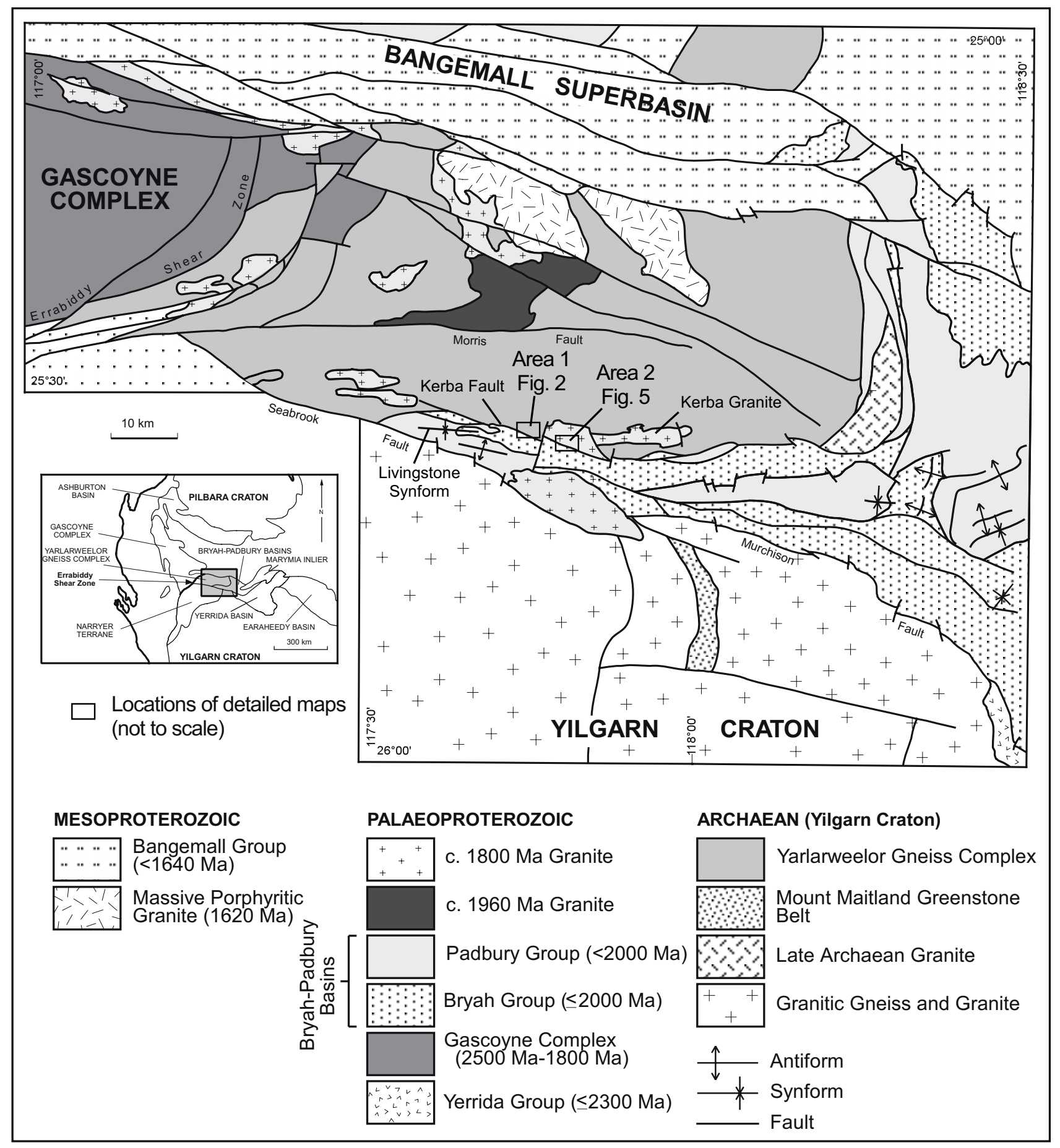

Figure 1 


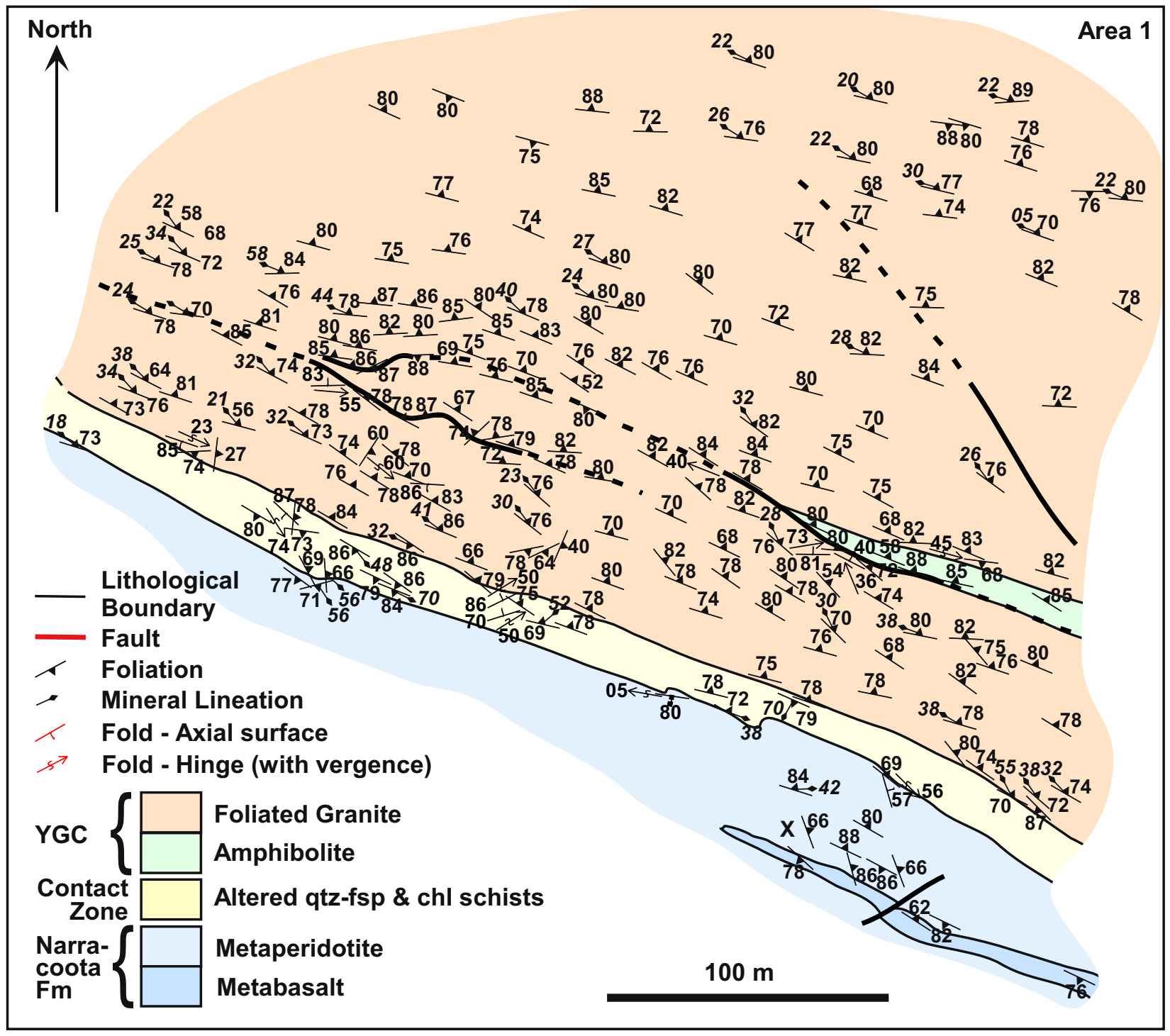




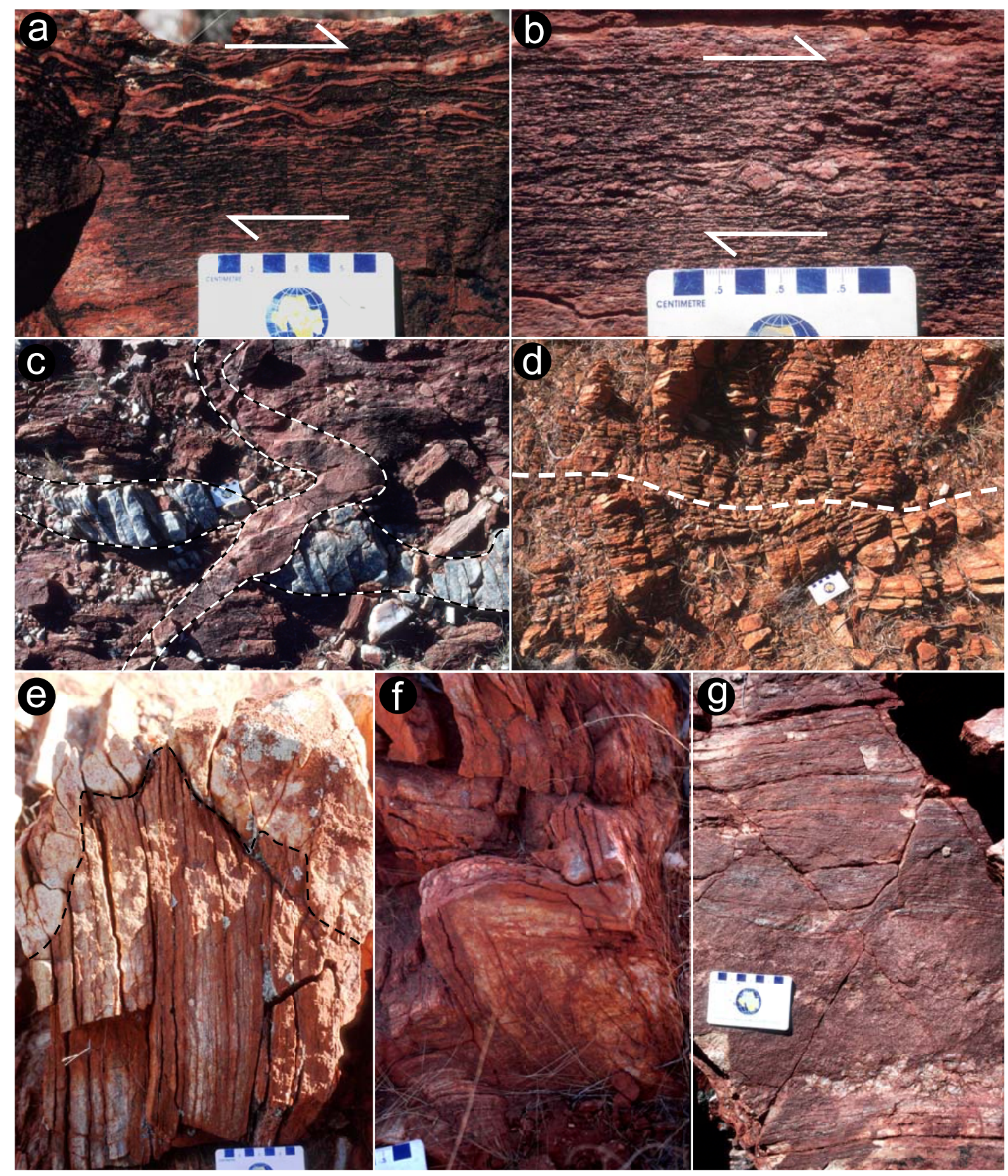

Figure 3 


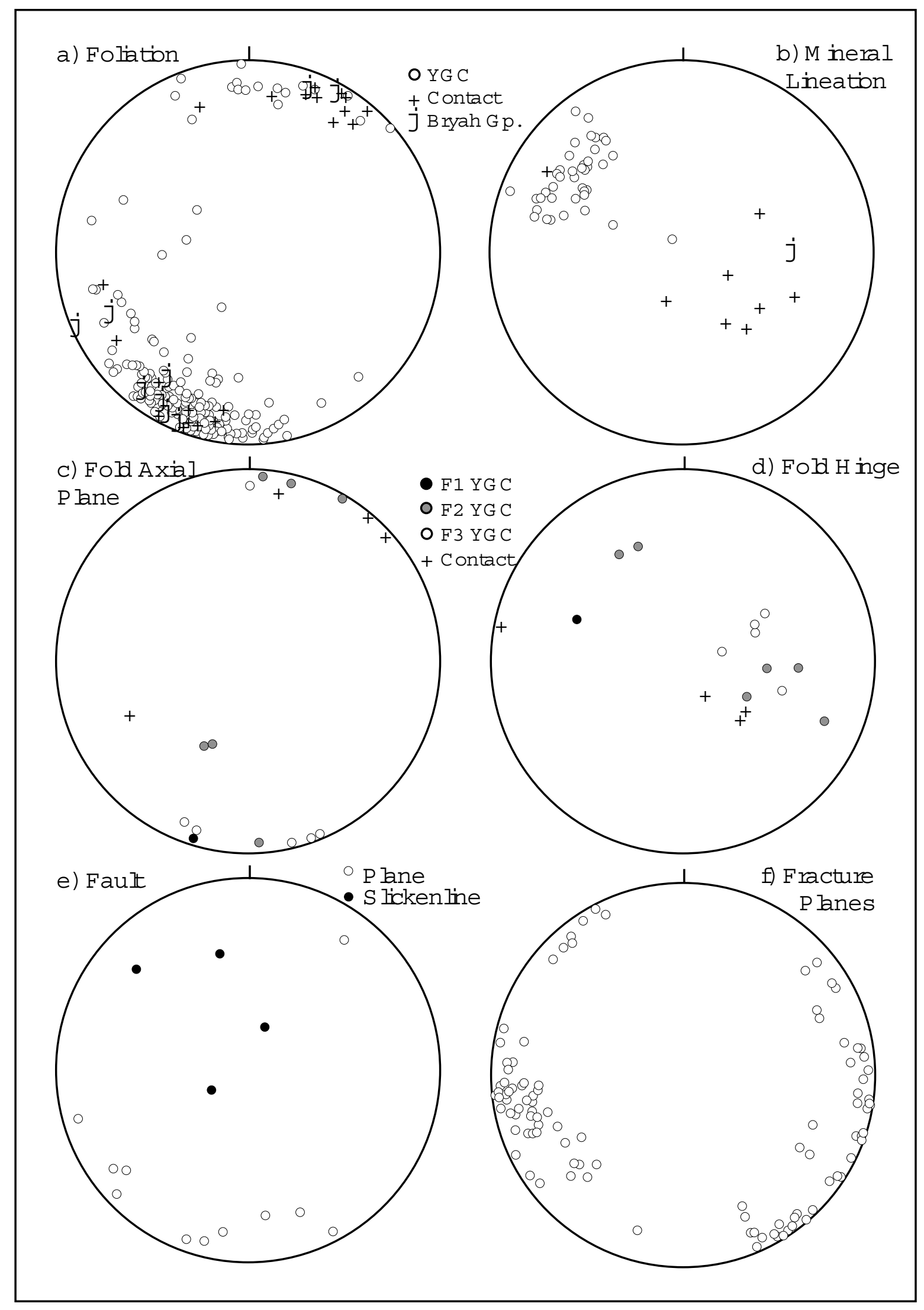

F giure 4:A rea $1: S$ tructuralD ata 


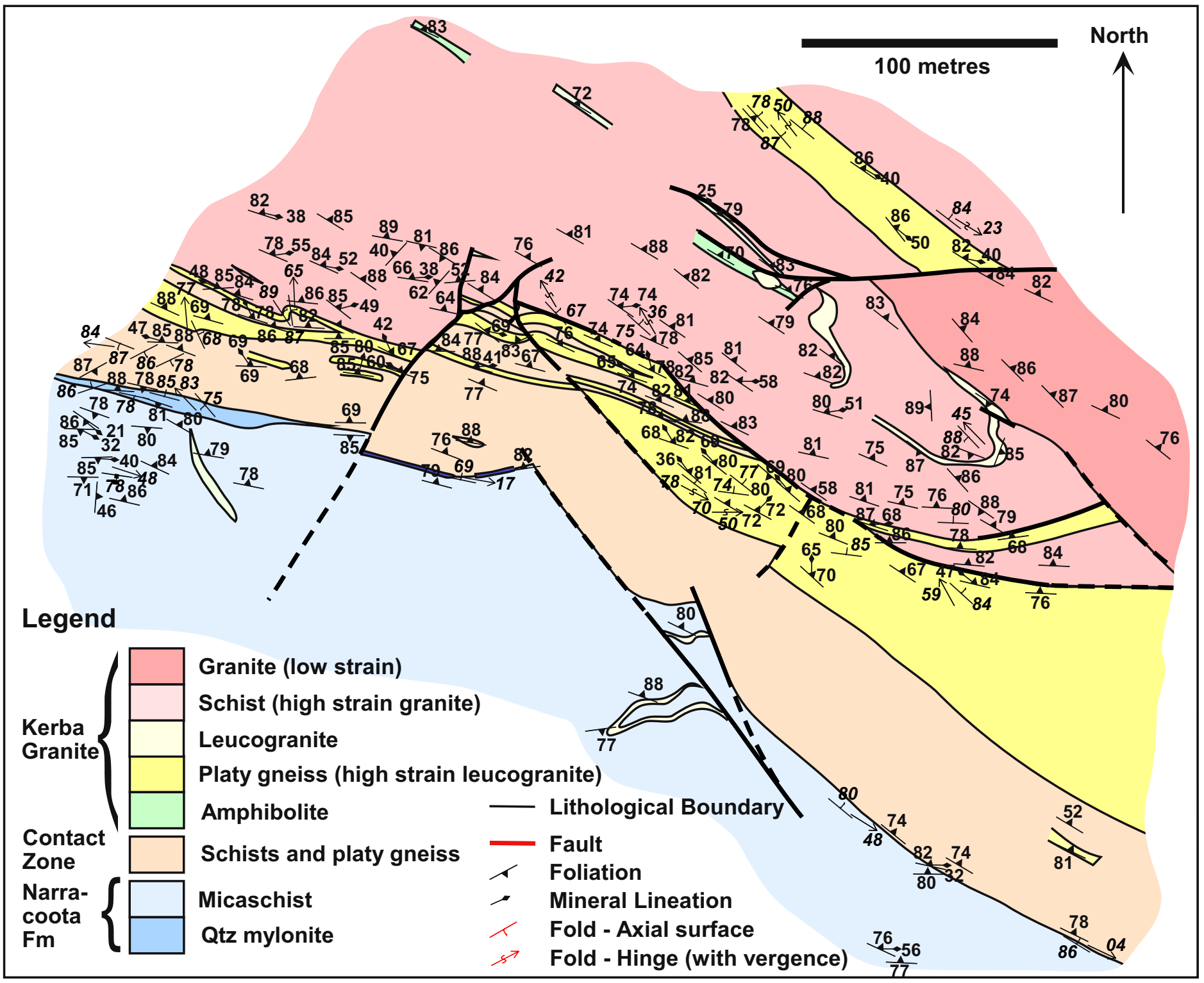

Figure 5 

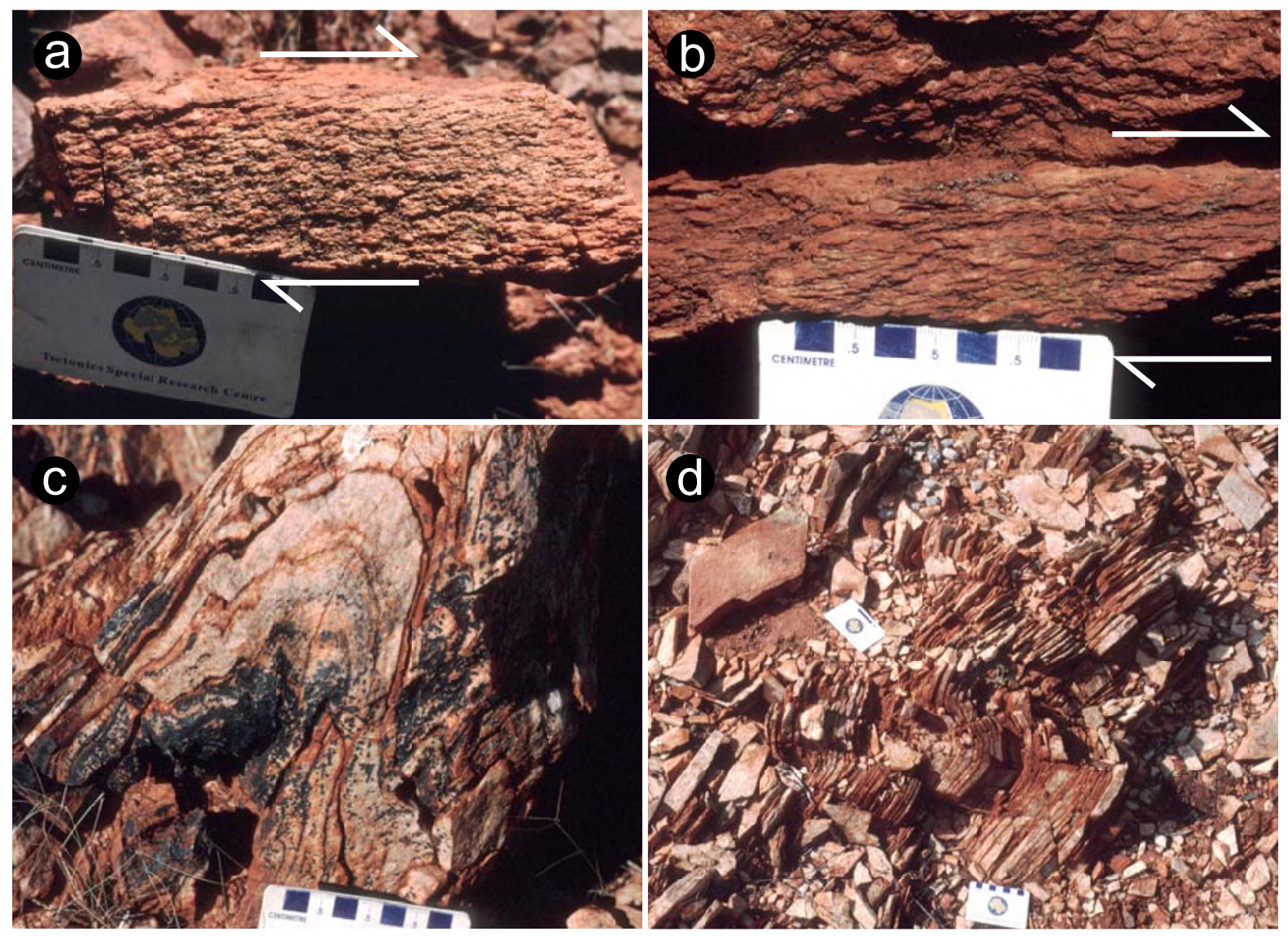

Figure 6 


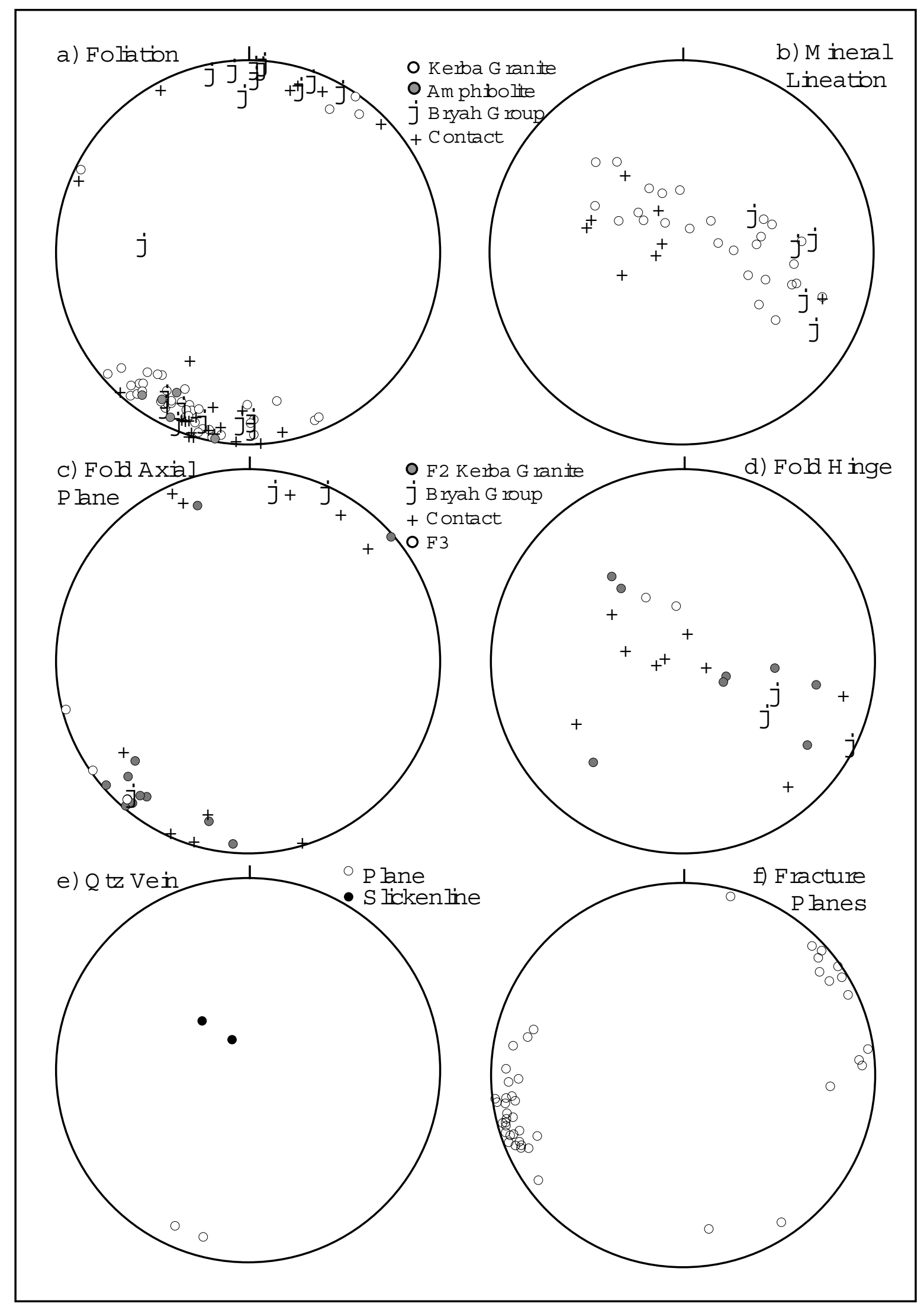

F gigure $7:$ A rea 2 S tructuralD ata 


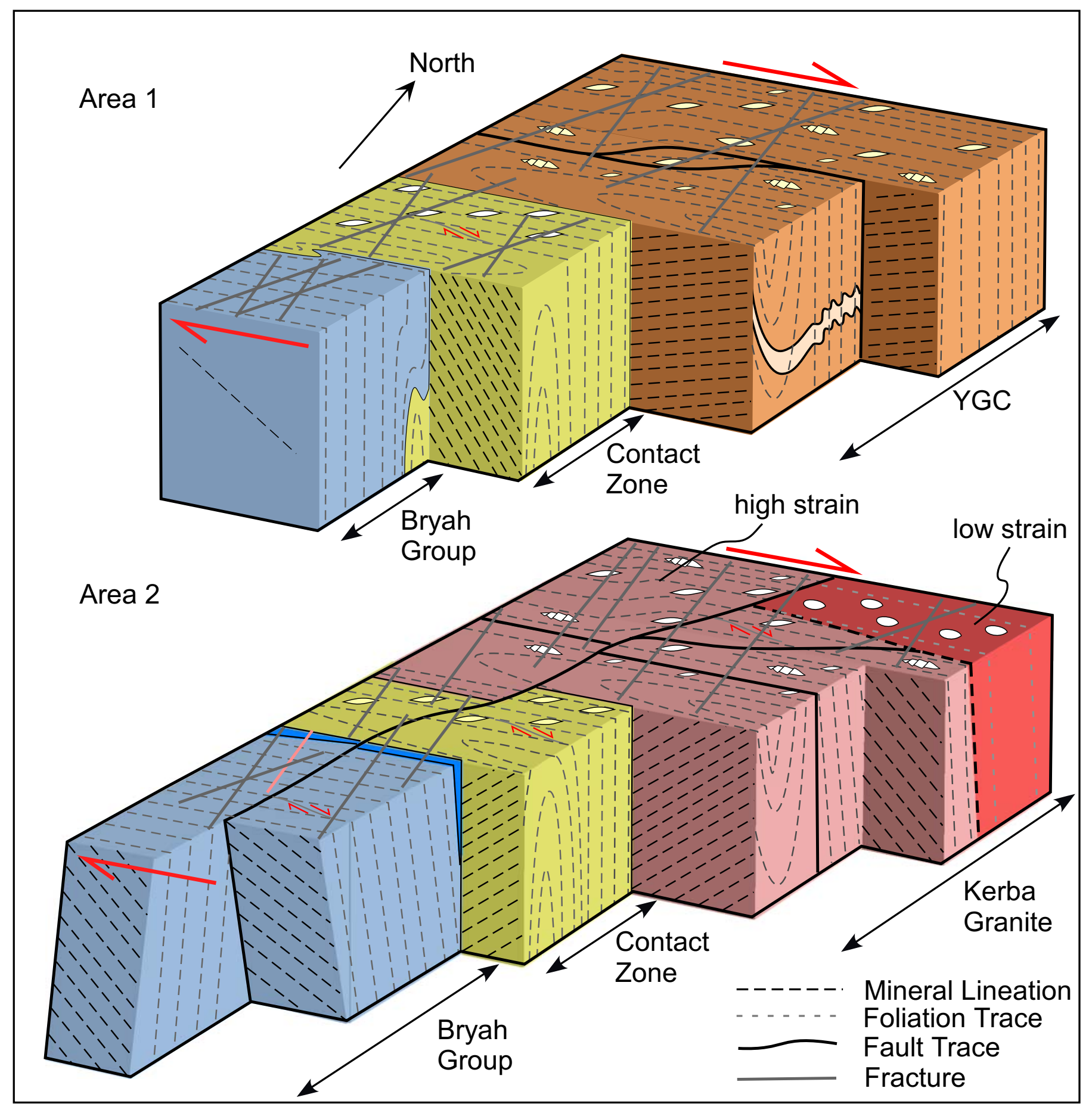

Figure 8 


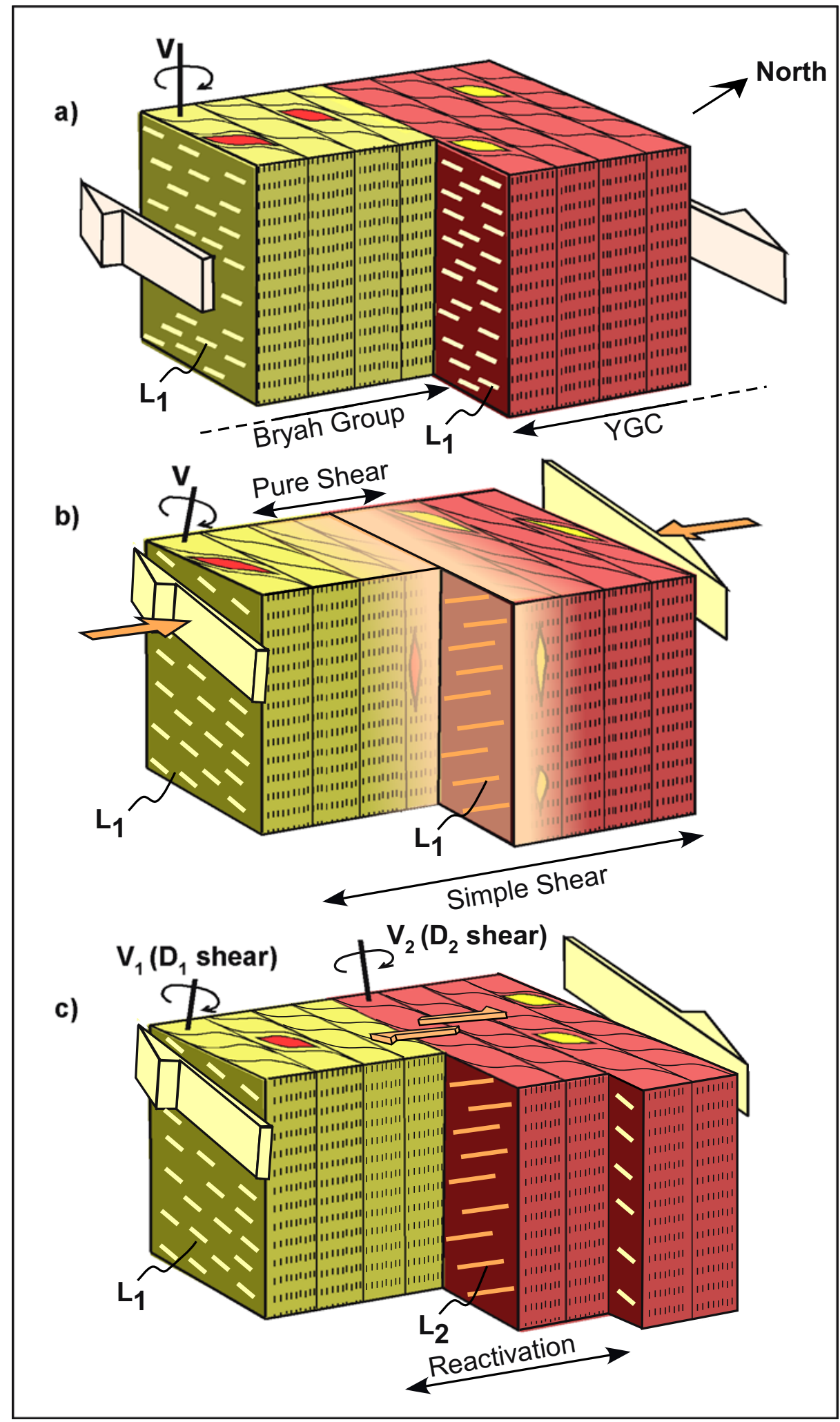

Figure 9 